\title{
BELONGING AND RETURNING HOME: DECONSTRUCTION OF LATVIAN RETURNEES' NATIONAL IDENTITY
}

\section{Inese Š̄ūpule}

Dr. sc. soc.

\section{Evija Kḷave}

Dr. sc. soc.

\begin{abstract}
The aim of this article on Latvian returnees' national identity is to get understanding of whether and how the forth and back migration experience affects returnees' sense of national identity. Different dimensions of national identity (territorial, political and cultural) have been analysed, both for their emotional and instrumental aspects. As empirical data, 18 semi-structured in-depth interviews with Latvian nationals who emigrated between 1991 and 2011 and returned after 2010 were analysed. The study acknowledges Hedetoft's statement that migration processes affect the growing variability of belonging: one can have several 'homes' and 'identities', as identifying with one country does not exclude identification with another, whether that is the country of origin or of residence. However, the formation of strong supranational identity, i.e., the sense of belonging to Europe has not been manifested among Latvian returnees.
\end{abstract}

Keywords: Latvia, return migration, returnees, national identity, social constructionism, Europe

\section{Introduction}

Since the beginning of the $21^{\text {st }}$ century, the population in Latvia has decreased by $9.1 \%$ (Hazans, 2013: 66). Both, demographic and long-term emigration processes have influenced the decrease. Numerically the greatest movement was observed between 2004 and 2010 when approximately 200,000 people emigrated from Latvia (Hazans, 2011: 76). Although in recent years the amount of emigrants tends to decrease, several thousand nationals still leave the country annually. Concurrently the return migration process takes place when after years spent in emigration, people return to their country of origin with no immediate intention to re-emigrate as it is in case of circular migration. Similar processes can be observed in other Baltic States, however, the migration processes in Estonia are less active 
than they are in Lithuania and Latvia, but, in comparison to Latvia, return migration in recent years has been more active in Lithuania.

Due to the globalisation debate, a lot of attention has been paid to the impact of migration on national identity in receiving countries (for example, Guibernau, 2007; Brettell, 2015). Many studies have analysed identity construction of Latvian migrants abroad (Buholcs \& Tabuns, 2015; Jurkāne-Hobein \& Kḷave, 2015; Kaprāns, 2015; Saulītis \& Mieriṇa, 2015). Comparably few studies have focused on returnees' adaptation and selfperception after returning home (Barcevičius, 2015; Boccagni, 2013; Hazans, 2016; Kḷave \& Šūpule, 2015; Williams \& Balaz, 2005). However, there are almost no studies on the emotional charge that recent Latvian return migrants invest in the place, language, symbols and beliefs and how do they reflect their belonging taking into account their migration experience.

The aim of the research on returnees' national identity is to obtain an understanding of whether and how the forth and back migration experience affects returnees' sense of national identity, and what dimensions of national identity (territorial, political and cultural) along with its constituent elements return migrants attach meaning to. In addition, the authors were interested in what ways the migration experience affects the formation of a supranational identity. Therefore, the research analyses different facets of the sense of belonging to Europe as a separate dimension of national identity.

\section{National Identity of Returnees as Social Construction}

For the purpose of understanding national identity the authors lean on the social constructionist approach which looks at identity as a discursive phenomenon that is being continuously modified and articulated situationally within the process of interaction. In addition, it should be rather noted that there are many overlapping identities, not one definite and fixed identity, as identities are situational and inconsistent. For example, in the context of migration returnees in Latvia can present themselves as Latvians or host country residents, or emigrants (Latvians abroad), returnees (Latvians who have returned from other countries), etc., but these identities are not fully "open", as they are determined by the discursive resources, available to the individual (Billig, 1996/1987; Hall, 1996; Potter \& Wetherell, 1987). The authors consider that national identity is a discursive construction, based on social categorisation and socially constructed conceptions of common origin and cultural differences. National identification is based on categorisation, related to contrasting 
one group to others, division in "we, as nation" and "they, the others" (Hall, 1992; Jenkins, 2008/1997; van Dijk et al., 1997; Wodak et al., 1999).

A number of identity scholars have tried to distinguish definite national identity dimensions for analytical purposes. For example, Montserrat Guibernau has distinguished five national identity dimensions: 1) psychological, which characterises emotional affiliation; 2) cultural (values, convictions, traditions, customs, language, experience; culture helps to imagine one's community as different from the others); 3) dimension of territorial belonging which includes opinions on home as a place, scenery, nature; 4) historical memories which allow a person to feel proud of his or her country, gain inspiration and energetic elevation for their roots; and 5) political dimension, which consists of civil links on individual level: responsibilities, rights, values, loyalty to a particular national or supranational formation (Guibernau, 2007).

The authors in their empirical analyses draw on a modified Guibernau's classification. The territorial dimension has been viewed both, as belonging to a local area, and belonging to Latvia, as well. The political dimension has been looked at in relation to political participation activities, interest in political resources in a certain community and attitude towards citizenship status either in Latvia or in the country of residence. The analyses of the cultural dimension focus on practising traditions and the meaning of the language in stories told by returnees, as well as using cultural markers in distinguishing their community from others. The dimension of European affiliation has been analysed separately, taking into consideration several aspects - territorial, cultural and political affiliation to Europe/ European Union.

Special attention within the analyses has been paid to the psychological aspects of return migration and identity transformation as a result of migration experience. One of the hypothetical assumptions of the analyses has been raised under the influence of Nan M. Sussman approach (Sussman, 2011); presuming that a sense of affiliation to the country is an essential element of returnees' self-concept, and it determines the re-integration process upon returning. According to Ulf Hedetoft, because of migration processes, there is an increase in affiliation variability - one can have a number of "homes" and "affiliations" (Hedetoft, 2002: 13-14). Conversely, a study on return migration in Lithuania served as the basis for another hypothetical assumption, that the most important ties, which facilitate the return and sense of belonging to the state, are family ties, as in Lithuania the main reason for return is social links: family and relatives (Garbenčiūtė, 2012).

Does the migration experience have any impact on the formation of supranational identity, and what is its significance in respect to one's 
national sense of belonging? There were three hypothetical assumptions about the European dimension of Latvian return migrants' national identity. Firstly, the emigration experience has strengthened the European dimension of one's national identity taking into account that in most cases the host countries were countries belonging to the European Union. Secondly, European cultural identity is rather strong having its roots in pre-war period (the first period of Latvia's independence, 1918-1940). Thirdly, European political identity is rather weak due to several factors: perception of the EU as a similar geopolitical union to that of the former Soviet Union; perception of political area of the EU as separated from the national policy; limited opportunities of Latvian politicians to influence EU level political decisions in favour of Latvia; poor knowledge on European level institutions, decision making processes etc.; and low trust in political power in general.

\section{Methods and Data}

For the information about Latvian returnees' national identity and its different dimensions, a qualitative research design was used. The study draws on 18 semi-structured in-depth interviews with Latvian returnees within various groups of age and social status, who left Latvia within a period from 1991 to 2011. The study target group were people who lived and worked in emigration for at least one year, and have moved back to Latvia after 2010. The authors were not concerned with circular labour migration, emigrants returning for a vacation or school holidays, nor for an extended homeland visit without the intention of remaining in Latvia. The authors neither interviewed people who emigrated only for their studies having a plan to return after their studies would be finished. The authors were concerned with those returnees who emigrated for indefinite time (with or without intention to return), decided to move back and intend to remain permanently in Latvia. All interviews were carried out between February and November 2014. The length of the interviews was on average between 60 and 90 minutes. The interviews were audio-recorded and then transcribed. For detailed information on informants' age, emigration countries, time spent in emigration, occupation and interview language see in Appendix.

At the beginning of each interview the informants' migration experience in general was elicited, from mobility within the country of origin to emigration and return migration motives and experience. Questions concerning returnees' national identity covered the following issues: the place in Latvia where the informant feels linked to; the importance of Latvian as a native language; situations in which the informant feels 
connected to other Latvians/residents of Latvia; meaning and celebration of national and traditional holidays; participation in national elections in the country of origin; maintaining or change of the citizenship; things, people or circumstances the informant missed while in emigration. In order to explore the European dimension of returnees' identity the authors asked questions about informants' general sense of belonging to Europe and their attitude towards Latvia's accession to the EU.

Data analysis was performed using the standard qualitative data coding procedure, starting with the open coding and identifying the main data structuring themes. In the further process of analysis both axial and selective coding were applied (Neuman, 2006: 415-418), allowing to determine returnees' national identity discourse themes and topics in each of primary defined national identity dimensions - territorial, political, cultural and European dimensions. Thus, the basic structure of the discourse under investigation was obtained. Theme and topic categorisation, in its turn, allowed the authors to see what elements informants include into their discourse, which aspects of the problem they pay attention to and which aspects they ignore, thus determining which topics are more significant and which are less. The analysis of in-depth interviews has been structured according to the above-mentioned returnees' national identity dimensions.

\section{Data Analysis}

\section{Territorial Dimension}

Territorial dimension has been viewed both, as belonging to a particular locality because belonging to Latvia develops through definite and specific prism of one's biography, and as belonging to Latvia as a territory with its characteristic climate and landscape.

It is characteristic of most interviewed returnees that, at least in the beginning they returned to places where they emigrated. Comparatively less common are the cases when the place to return to differs; it is mostly due to rational and economic considerations - the purchase of housing at the particular location, better job opportunities, more convenient household conditions.

The study shows that territorial sense of belonging can develop with more than one place/locality in Latvia. Essentially, informants talk about two, rarely about three towns/villages they feel connected with. First, it is their birthplace where they spent their childhood and school years. If active life does not take place there anymore, and there are no social links (family, friends) with it, typically, the link with the place disappears and the belonging is a mere formality. Secondly, it is a place where the informant lives, usually works in the current stage of his/her life. In many cases, it is a 
place where the informant has returned to after emigration. Thirdly, it can be the birthplace of one's partner, which has broadened the individual's social network and through this network, a certain sense of belonging has been developed to one more locality. All the above-mentioned types of localities mostly characterise cultural dimension of territorial identity, which is based on social links.

Locality is of great importance in the informants' stories as the individual's social and cultural foundations of national identity are interpreted through it. With respect to the birthplace, informants speak about their families and place specific culture (the language and lifestyle). It can be seen, for example, in the following quotation from an interview where the informant is very clearly aware of how the particular locality, its culture, community and environment have shaped his sense of belonging to Latvia in general:

'I always feel very strong belonging to Latvia! I have always felt; possibly, it comes through Mazirbe la village in the Latvian countryside]. In my childhood I spent all the summers in Mazirbe, this feeling comes from there. The sea, which is there, woods, which have always been there; it somehow has been in me since childhood. There is that energy storage in Mazirbe where I accumulated the energy; Mazirbe is that nature of Latvia. While in Germany the energy battery usually depleted, then I came to Latvia, and it was charged again.' (13)

The main constituent elements of territorial identity are social ties and the environment (nature) which determines strong emotional affiliation to a particular place. Social ties - relationships with family members, relatives and friends who live in the particular place - are one of the major constituent elements of territorial identity. Those returnees who have not only been born, spent childhood and school years, but also live in the same place (before and after emigration) and are connected to this particular place by social links feel stronger sense of belonging to the place of their origin. That is exactly the close social network, which makes up the sense of home - close emotional belonging to a particular town:

'Yes, I missed people; those, around me. When you walk in Liepaja [a city in Latvia], you greet people, like in the country; a lot of acquaintances.' (8)

'Sure, friends, relatives are here in Latvia. If you get on well with your relatives, like my Mum and Grandma, you see that a person gets older every half a year. It makes me think; about such a thing that one day someone can be gone. Here I have more possibilities to spend time with those people. It is important for me.' (9) 
Alongside with social - emotional ties, economic (job) and educational ties play important role in building territorial instrumental belonging. Search for work and study purposes are two of the main causes of internal migration, when building up an independent life. It can be migration to the closest town, regional centres and the capital city of Riga. Active workplace can also become the basis for territorial identity formation. However, it is a sense of belonging, which is rather based on pragmatic and instrumental considerations:

'My birthplace, the town where I was born also attracts me. I can go there now and then and regain strength, feel the joy of nature, meet relatives, feed on energy. That is it. And then Riga again. I have got used to Riga being my home.' (11)

Talking of important localities, informants mention their psychological feelings aroused by life in a particular place. Mostly they are positive emotions - peace (as opposed to stress), inner psychological balance, feeling improved by social network in the particular place, that you belong; you are not a stranger. Informants compare the quick and intensive pace of life, which is characteristic to the host country with comparatively calm and slow atmosphere in towns and cities in Latvia, a possibility to meet and spend time together with personally important people (family, friends). Secondly, emotionality is revealed through stories of environmental elements (streets, the sea, sand, rivers, woods), which are a powerful part of returnees' national identity as a whole. It is interesting that describing nature as an important element of establishing the ties with Latvia, returnees, mostly being town-dwellers originally, oppose the urban environment in the host country to natural rural/wild environment in Latvia:

'You sleep in a bed in England and dream how cool it would be if you could hear frogs croaking in a pond outside. There is nothing like that. We had a park next to our house; the lawn was mown down, but it does not even smell as it does in Latvia; when mown down, it smells of grass. It was the thing I missed. There is nothing like that. You just sit on the asphalt.' (2)

'The nature is very much missing. There is also pretty nature, but there is everything... you can go for a walk in a park, but it is not in the wild, in the open air.' (6)

\section{Political Dimension}

Many of the return migrants interviewed do not grant a big emotional or political significance to the national holiday, Latvian Independence day on 18 November. While in emigration, part of the informants celebrated the holiday because of children, others admit that it was an ordinary day: 
'For us Independence Day is subordinate as it is our grandfather's birthday then. Ok, we celebrate a little. Children need to be taught those patriotic sentiments, but I do not feel that way myself. Go to see the fireworks, something else; discuss why it is so, but it is more for children, not so important for adults.' (8)

Justifying, why this holiday was not celebrated while living in emigration, informants refer to the fact that this is not a public holiday in the host country. Therefore, one should make special efforts to create the festive feeling and observe certain traditions or rituals. At the same time, when speaking about traditional folk holidays, such as summer Solstice such obstacles are not mentioned.

Characteristically that the celebration rituals were observed in families with children thus carrying out children's civic education. This shows, that it is important and parents wish their children to be aware of their connection to the Latvian state and they want to build their children's sense of belonging to Latvia. Overall, it is observed that national holidays are not ignored neither in Latvia, nor in emigration, but in returnees' stories, they fail to comply with the collective community awareness and civic mobilisation functions.

Another aspect characterising the political dimension of national identity is participation in national elections. In compliance with Latvian legislation, emigrants who are citizens of Latvia have the rights to participate in the elections of Latvian and European parliament, as well as in Latvian referendums. It has been concluded in the study on Latvian diaspora political involvement that emigrants' participation in elections is influenced by several socio-political factors: the electorate level of political competence, links between and responsibility level of the electorate and politicians, the quality of political offer, social and civic activity level of the diaspora, as well as the technical side of voting procedures (Lulle et al., 2015).

Although the interviewed returnees had participated in elections, their participation, like celebration of national holidays was more formal as it is characterised by low political competence and weak civic patriotism. Informants, when interpreting their motivation, mention such motives as civic duty and responsibility, doing functions imposed by the society, attending a social event - a chance to meet other emigrants from Latvia. One of the returnees links participation in national elections with considerations on returning to Latvia:

'Motivation was that it was not all the same what is happening here. Of course, you are there and understand that you want to go home one day, and this is why it was done. Theoretically you understand 
that those two votes will make no difference, but there is a sense of responsibility that you must do it.' (2)

In some interviews, political and ethnical sense of endangerment as reasons for participation in elections can be identified. This is a characteristic to Latvians as ethnic and political community in general (Zepa et al., 2005, 2006; Šupule et al., 2004). Since regaining independence in 1991, there is evident ethnic division of political parties in Latvia. Statements that one has to participate in elections to vote for any Latvian party regardless of its political offer, in order to prevent the prevailing of pro-Russian political forces, are indicative of Latvians as endangered majority manifestation:

'What stimulates going [to take part in elections]? Actually, mass media zombies, pressing to go so that some Russians do not go, and things like that, but not so that I know that this party is the right one, which [to vote] for; that is the main thing.' (8)

Higher civil activity is connected with a perceived threat to national identity elements, as it could be seen in the Referendum on the Russian language as the second state language in 2012. This referendum met with the highest diaspora activity of all elections and referendums. 39763 voters, which was $72.71 \%$ of all the registered nationals voting abroad at the time participated in it. Although the interviews did not contain a separate question about participation in the referendum on the language, the subject was raised by returnees themselves commenting their political involvement in general:

'The referendum on the language, yes. I suppose it was the only one where I went to take part. [... I wanted the Latvian language in Latvia, so that the Russian language did not overpower. It was important; exclusively for the Latvian language.' (6)

Institutionally significant constituent characterising the political dimension of national identity is the returnees' attitude towards the Latvian citizenship and a possibility to change it to the host country citizenship. When investigating this issue, it is important to take into consideration that citizens of Latvia were denied the right to have double citizenship until 2013, which could be a restrictive factor to change the citizenship, although none of the informants mentioned this as an impediment when making the choice to maintain or change the citizenship. The study did not identify any case of deliberate and purposeful desire and action to acquire the citizenship of the host country. Only in one case, when permanent emigration and assimilation in one of the host countries had been originally planned the informant admitted that her spouse and her had considered the change of citizenship. During the five years, they spent in emigration this couple's sense of belonging to Latvia got stronger; they became aware that they would always be strangers, not 
locals in their host country and finally they made a decision to return to their country of origin and maintain the citizenship of Latvia:

'We were not satisfied with the situation in Latvia, exactly - in social and political sphere. Somehow, we got an idea to go somewhere, where the social life is better organised, where there is order, where politicians are interested in their nation. Fortunately, we maintained the citizenship of Latvia. But at the beginning, we had an idea that this is going to be our home. We were going to stay forever, and we wanted to get the citizenship. But then, as years passed by, little by little we had a feeling that we do not belong, this is not the right place for us, it is cold here, and it is unlikely we will stay here; and then we gave up the idea about the change of citizenship.' (12)

In those cases when the emigration was planned as temporary only, the issue of the change of citizenship was not even raised. The analysis of the discourse of returnees is indicative of maintaining the citizenship. The interviews did not reveal any pragmatic motives for obtaining the host country citizenship; most likely it is due to the fact that equal rights and state-guaranteed range of services was available to citizens of Latvia as a European Union member state and locals.

Living conditions and financial situation had been better in emigration than in Latvia for a number of informants. Belonging to Latvia as a state is not associated with the state-provided sense of security, job opportunities or social protection. Returnees speak negatively of all the above-mentioned aspects; moreover, economic factors had been main motives for their emigration:

'As soon as you need to start thinking about what and how to eat, what to buy, what you can afford to buy. At that moment it somehow seems, cannot the state really do something to straighten out the situation so that everybody has a job and can live normal life. Then you start looking more sceptically at the state, and start thinking whether you really need to go and live somewhere else, if nothing changes here.' (2)

\section{Cultural Dimension}

The cultural dimension in the study is defined in compliance with the interpretative sociology paradigm according to which culture is a social reality resulting from subjectively motivated individual actions and interactions, and it is composed of various social agents, institutions and phenomena. Ethnicity, traditional folk festivals, culture and sports life, sense of home - the entirety of all these themes and the significance attached to them characterises the culture dimension of returnees' national identity. 
Ethnic pride referring to the common origin, myths, culture and language of the ethnic group was manifested in several interviews with returnees:

'I am really proud to be born a Latvia, proud of growing up here. I always brought out that I am from Latvia, I am Latvian.' (6)

Ethnicity, Latvian identity was also attested by celebrating the summer Solstice. The summer Solstice is a holiday when the interviewed returnees feel united with other Latvians. The traditional folk festival brings together the ethnic community. Several returnees, when speaking of this holiday in the interviews stressed that none of the other holidays in the emigration had been so important to them as this one, as this holiday differs from all the others which both, in Latvia and in their country of residence had been celebrated more or less alike:

'To me personally the most important holiday is the Ligo holiday [summer Solstice]. You usually sit at home at Christmas; Christmas is alike everywhere - England or here, all right, here we have snow during Christmas time, there is no snow there, but the processes are mostly the same. But Ligo holiday, it is something for me - it is a holy thing.' (2)

In the returnees discourse on their ethnicity one of the most interesting, although not typical issues is about fragmented ethnicity when an individual does not feel unequivocally belonging to one particular ethnic group and thus problemises not only his/her, but also other community members' ethnicity:

'Somehow a very conservative opinion [in the society] on the definition of Latvians. Because, for example my boyfriend [a Russian] is much more patriotically minded and involved in all the issues on Latvia that me. I consider myself to be a Latvian, although I come from a mixed family, but we somehow had maintained the Latvianness. Now I do not really know what my opinion is, but I understand that the whole thing should be re-defined.' (16)

Several Latvian returnees of Russian origin spoked about their difficulties to present themselves as Latvian Russians abroad. Returnees of Russian origin feel to be affiliated with the state of Latvia, but they do not feel the sense of belonging to Latvians as an ethnic group. To them belonging to the Russian ethnic group is significant:

'The most interesting thing is that I need to explain all the time and to everybody that I am a Russian, but I come from Latvia. They do not understand that the Latvian language is not at all like the Russian language. We do not choose where to be born. I am happy I was born in Latvia.' (10) 
One returnee expressed the point of view that ethnic cleavages are not so strong in emigration context, because both Latvians and Russians are friendly and united by the fact that they are Latvian residents:

'It was like a holiday for me when I met someone from Latvia. You can meet up and talk to the people, and there is somehow the atmosphere. It does not matter if it is a Latvian or a Russian. If the person is from Latvia, it is enjoyable all the same.' (11)

In another case, a returnee (a Latvian) reflects on the way the host country started influencing his ethnicity and its characteristic features, thus promoting assimilation process into the host country society. Emigration in this case made the person to define one's identity as a denial of another identity and to draw the boundaries of one's ethnic identity:

'I started feeling that after five years spent in Germany I was becoming a bit like a German myself, became more reserved, more monotonous, kept calm; the emotional being, the Latvian which is inside me, intuitive, creative, emotional started fading. Do I want to become even more like Germans? Most probably, I do not. I want to be like I am, live where I am, in the surroundings which are typically mine.' (13)

When asked if they followed Latvian culture and sports events on the world stage, almost all the informants answered in the affirmative. Success of various artists and athletes, large-scale Latvian culture events in Latvia invite feelings of national patriotism, the pride of the people and the country, emotional sense of community with other residents of Latvia. In this context, the artist or athlete's belonging or not belonging to the informant's ethnic group loses its significance and the key is their national belonging to the Latvian state. Thus, culture in the sense of artistic and intellectual activity, and sport does not only consolidate ethnic community, but also civic community, develops not an ethnic, but a civic nationalism discourse:

'Always happy when I read about bobsleigh, success in skeleton. This is where I feel patriotism. In music, too. Then I am happy for Latvians. Such feeling of togetherness. Yes, I feel myself as a patriot of Latvia and in certain ways a patriot of Latvians; the basis for me is Latvia as state.' (4)

'When Latvia gains global success, I am happy for it. This way I feel united; that is the place where I was born, those are people who I live with, and I am a part of this nation. Even though I am a Russian who was born in Latvia, I am a part of the nation.' (11)

Language has one of the most significant roles in the formation processes of ethnic self-consciousness and identity in Central and Eastern European countries (Schöpflin, 2000: 116-127), where Latvia belongs as 
well. In the returnees' interviews, the Latvian language is a topical issue, first of all, in the decision-making context regarding return to Latvia. Longing for life in Latvia is connected not only with the nature, relatives and the usual environment, but also with a willingness to speak in one's native tongue where it is the easiest to express oneself and understand others. The desire to speak Latvian refers to practical everyday situations as well, for example, visits to physicians. Common language and a possibility to speak freely on philosophically deep issues are at the basis of closer social relationships, and the language barrier does not allow developing such relationships where there are no users of the Latvian language:

'Although we knew the language very well, we could communicate fluently, as soon as there was a more philosophic topic to be discussed, we immediately felt we lack the right words. In Latvia, it is possible to form deep relationships with people just because of the language, because it is possible to express one on complicated issues as well. I missed a possibility to make friends with people.' (12) Secondly, the Latvian language, the knowledge of it is significant with the reference to children, formation of their national identities. Parents wish their children to learn the Latvian language, to speak and study in their native language. However, while living in the host country, parents have observed gradual linguistic assimilation of their children into the host country community (see also Kḷave \& Šūpule, 2017). For example, children, when speaking among themselves, speak English, as it is easier for them. Therefore, there are parents who, being aware of the assimilation, make a decision to return: 'Our girls started becoming more English than Latvian. They were four years old, and they did not know elementary words in Latvian, although we had a rule that we speak only Latvian at home. But they, when they were playing, they spoke only English. They went to school; everything was in English for them.' (5).

An important topic of returnees national identity discourse is home, sense of being at home. It is characterised by maintaining active links with family member, relatives and friends living in Latvia. In several cases, informants regularly visited Latvia for several weeks or even several months, maintaining strong links with their loved ones' social network. Visits to the country of origin are considered to be a special transnational practice, which is in many ways connected to return migration (Carling \& Erdal, 2014: 4). The social network and the environment have made it possible for returnees to feel at home in Latvia upon return, to belong to a particular place and country whereas in the country of residence, regardless of successfully passed everyday life issues they still felt strangers: 
'I spent a lot of time in Latvia. Practically all the university holidays and most holidays at work were spent in Latvia. I never felt as an outsider in Latvia. I always felt like I was returning home from a temporary absence.' (4)

The topic of home as a place where an individual is territorially and socially connected to characterise also a transnational sense of belonging, which means that identification with one country does not exclude identification with another one. Informants admitted that in emigration it had been difficult to say where exactly their home was - in the country of residence or the country of origin:

'Sense of home? In Liepaja [a city in Latvia] indisputably, unquestionably. Although all those years, when I was coming to Latvia, I was staying at my Mom's. Then, of course, I was saying - ok, I am going home soon. Home was in Ireland. I needed a couple of days to adapt to be understood, not to be pulled back to Ireland. Then I wanted to stay in Latvia longer, but if it was too long, I did not want back to Ireland. Then, when I returned to Ireland, I needed two weeks again to adapt to living there.' (9)

In some cases upon returning to Latvia, returnees have developed transnational lifestyle and transnational identity features can be observed, for example, attaching importance to more than one country and social group. In these cases, economic and social links with the previous country of residence are of greater significance than political, cultural or emotional ties. Transnational lifestyle and formation of transnational identity are characteristic of highly qualified specialists - returnees working in the spheres on demand in the labour market (IT, for example) who have built professional social network in the previous country of residence as well:

'I do not feel any strong ties that I would be missing - home or anything like that. I have always felt very well and interesting in London; I have quite successful career there, interesting projects, but I simply like it better here, in Latvia. Because people here are more interesting. The mentality is more like mine, and life is a little simpler. However, there are few people in Latvia being professionally on the same frequency. I feel I belong to Latvia, I am Latvian, but I do not feel like other Latvians.' (2)

The emigration experience has affected returnees' stand regarding the preferred place of residence, but this does not mean that they definitely would prefer living in Latvia or in another country. In some cases emigration has promoted the sense of territorial belonging to Latvia, irrespective of the fact that before emigration a possibility to move to permanent residence in another country was considered: 
'We want to live in Latvia and we have finally found a place, because all that time we spent away from here, the six years, we constantly questioned ourselves where we wanted to be and what we wanted to do. The feeling that we are not in our shoes never left us in neither Norway, Spain, or Asia. And only here, in Latvia we found our house, the place in the country, and we finally have the feeling that we are where we must be, and do what we like to do.' (12)

Although most returnees mention Latvia, or even more precisely - a particular city or town in Latvia, as their preferred place of residence, in some cases an opposite opinion is expressed that the emigration experience has enabled one to realise the openness of the whole world and free mobility options, therefore a permanent place of residence in the territorial meaning is not of importance any more. One can reside in any place in the world. In few returnees' stories, we can see that global migration and open borders have changed their attitude towards their territory of origin. Along with the access to global space, the understanding of one's country of origin as a part of the open, global space is expanding. Such discourse is more characteristic of young people who do not have families yet and who do not deny a possibility of repeated emigration: 'For me Latvia is not anymore as it used to be. Closed space. Yes, because people are coming to us from all over the world. I do not feel that I would like to live in just one place. Whatever the country is like, I would like to live in various countries. To live for some time here and there.' (11)

\section{European Dimension}

The results of the in-depth interviews revealed that the general sense of belonging to Europe is mainly constructed on practical or instrumental arguments. A very important topic is that of mobility opportunities, and mobility is evaluated exclusively positively and as the main real benefit for everyone being a European citizen:

'That you can travel, there isn't that restriction, there are no visas,

you buy a ticket and go where you want, which direction your nose points to all around Europe.' (5)

Almost every informant, even not asked about his/her attitudes towards the introduction of common European currency in Latvia, covered this topic. Interestingly, we can observe both positive and negative attitudes. Those who have expressed their opinion in rather negative categories did not talk in terms of economic benefits or losses. The negative arguments were built around the loss of national currency as an implicit manifestation of national particularity and even the symbol of Latvia's sovereignty: 
'The only thing was the change to Euro, for that I was not ready yet. That is a benefit for foreigners, but I think that our old money was part of our nation, our state. Lats [Latvia's national currency before joining euro zone] are associated with Latvia. In a way I grieved that we lost Lats. That probably is one of the examples that emotional experience for a state, a nation can be the currency.' (11)

Some informants, especially those who are highly qualified, clearly demonstrated their positive attitude towards EU from the perspective of economic development, the access to and integration into Europe's wide markets etc.:

'I don't have antipathy to the European Union, to European institutions or other European nations. I would not have any objections, if there would be more integration both on the Baltic and European level. It was beneficial [for Latvia to join EU]. I can talk about economic reasons for 20 minutes. Economic conveniences. I think about material things, economics rationally.' (4)

Finally, the interviews data shed light on the construction of European identity as global scale identity in opposition to local scale identity expressed in terms of the sense of belonging to native village or native town:

'I think that more likely it is possible to belong to something tiny, something small, to some village. I think that I could say that I belong more to Liepaja [a regional city] or some small village rather than I could say that, yes, I belong to Europe.' (7)

In this quotation, one can explicitly see the significance of local territorial identity in the context of multilingualism and multiculturalism prescribed to Europe and even broader. On the one hand, there is the will to preserve the national (Latvian) identity, to keep national particularities, on the other - there is a sense of inevitable global citizenship.

The political dimension of Latvian returnees' European identity is very weak. During the interviews, the answers to questions concerning the informants' interest in European level political events or participation in the EU Parliament were rather scarce although the interviews were held at the pre-election period:

'I don't keep up with politics. Isn't it important? No. I trust those people, who are there and who do it, that they know what they are doing. Politics doesn't [interest me] at all.' (6)

'I follow up, but not so often as daily, but I try to refresh my memory, because I need it for work. I need to be informed. Have you participated in the European Parliament elections? Honestly, I don't remember. I can't tell, I don't know.' (11) 
The last aspect is that of the cultural dimension of European identity. If we look back at the period, when Latvia regained its independence in the early 1990s, the discourse "we are back into Europe where we have always been' was one of the most dominant public discourses. It was very important to stress the belonging to Europe, common history and West European culture in general. The interview data allow the drawing three main insights concerning modern European cultural identity of Latvian returnees. First, there is a will to stress the particularities and specifics of Latvian national culture, for example, when comparing different celebrations and/or national holidays. Secondly, culturally Latvia and Europe have been opposed to Russia and former Soviet Union. It is stressed that Latvian culture is rather European, thus Latvians belong to European culture, but Russians to Russian or Slavic culture. Thirdly, European culture is seen mainly in terms of lifestyle, not so much of different arts:

'It isn't possible to reject cultural influence from European countries. It is not possible. If one looks how people around dress and behave, they unambiguously behave like Europeans. If we compare now former Soviet Union and present Latvia, then Latvia is more European.' (11)

\section{Conclusions}

In the returnees' national identity discourse, greater meaning has been given to the territorially local and cultural dimension, while political and supranational or European dimension being of less importance. When defining the sense of belonging both, emotional and instrumental aspects are equally significant, although it must be emphasised that the reasons for returning are mostly emotional, and as in Lithuania (Garbenčiūtè, 2012) they are grounded on social links with Latvia: family, relatives, friends who live in Latvia. The study shows that returnees have maintained close ties with Latvia and their relatives also while living in emigration; this is consistent of the conclusions of the study carried out by Sussman (2011). The study also acknowledges Hedetoft's statement (Hedetoft, 2002) that migration processes affect the growing variability of belonging, because one can have several "homes" and "identities", as identifying with one country does not exclude identifying with another - country of origin or country of residence.

The most significant elements of territorially local dimension of national identity are cultural, social and emotional ties with the particular place. Returnees themselves did not pay any attention to the political aspect of local belonging. Instrumental factors (such as more convenient everyday life, wider social life or culture possibilities, and accessibility of a range of services) which make up the belonging to a particular locality 
are not of essential importance either. At the same time, the environment and inherent rhythm of life in a particular place are important; these constituent elements of territorial sense of belonging are referred to the cultural (in the sociological meaning) dimension.

Data analysis shows that, on the one hand, the political dimension of national identity is weak, which is testified by the attitudes towards celebration of national holidays, generally low interest in political developments in the country and the meanings attributed to participation in elections which are not characterised by national patriotism, strengthening the political community consciousness or motivation to influence the political processes in the country. On the other hand, disinclination to lose politically institutional affiliation to the country - indisposition to change the citizenship, active civic position in cases of endangerment to other national identity elements (participation in the referendum on the state language) give evidence that political dimension is important.

The language as the central marker of Latvian national identity is a theme, which is activated in connection with the return to the country of origin. The importance of children's knowledge of the Latvian language to their parents gives evidence on the role of language in forming the ethnic identity. A significant element of returnees' national identity is the traditional summer Solstice and its celebration. This holiday impersonates other elements of national identity, as well - Latvian countryside nature, being together with one's family, relatives, friends, and awareness of national uniqueness.

The European dimension of national identity sheds light on returnees' supranational identity formation. The emigration experience, contrary to our initial assumption, has weak or no impact on the European dimension of Latvian return migrants' national identity. The life experience in other European countries has rather strengthened the sense of belonging to Latvia than fostered the formation of supranational identity. This relates to Hedetoft's conclusions that psychologically it is easier to identify oneself with a narrower community with comparably clear boundaries and cultural traditions, but the EU project offers quite blurred and open understanding of the territory (the EU enlargement process) and traditions and values.

The European dimension is constructed mostly on practical and instrumental reasons, including the national security issue, not on emotional or psychological aspects. The European cultural identity of return migrants is based on the geographical location and common life style, and is in opposition to Slavic (Russian) culture. In its turn, the European political identity is not manifested in terms of belonging to common European political community, shared political responsibility or values. Nevertheless, the ignorant attitudes are not linked with the perception of the EU as a 
similar geopolitical union to that of the former Soviet Union, but rather explained by low interest in large-scale political activities in general.

\section{REFERENCES}

Barcevičius, E. (2015). How successful are highly qualified return migrants in the Lithuanian labour market? International Migration, 54(3), 35-47.

Billig, M. (1996/1987). Arguing and Thinking: A Rhetorical Approach to Social Psychology. Second edition. Cambridge: Cambridge University Press.

Boccagni, P. (2013). 'I'm not like all these Ecuadorians'. Promises and dilemmas of immigrants' selective ethnicity appropriation. Social Identities, 20:1, pp. 57-73.

Brettell B. C. (2015). Theorizing Migration in Anthropology. The Cultural, Social, and Phenomenological Dimensions of Movement. In: Migration Theory: Talking across Disciplines (ed. Brettell B. C. and Hollifield F. J.). Third edition. Routledge, pp. 148-197.

Buholcs, J. \& Tabuns, A. (2015). Latvijas emigrantu transnacionālo identitāšu izpausmes sociālo tīklu portālu lietojumā. Grām.: Latvijas emigrantu kopienas: cerību diaspora (red. Inta Mieriṇa). Rīga: Latvijas Universitāte, 128.-143.

Carling, J. \& Erdal, M. B. (2014). Return Migration and transnationalism: How Are the Two Connected? International Migraton, Volume 52, Issue 6, pp. 2-12.

Garbenčiūtè, L. (2012). Return Migration: Brain Gain and Possibilities of Adaptation in Lithuania. In: Grupès Ir Aplinkos 3, pp. 43-72.

Guibernau, M. (2007). The Identity of Nations. Polity Press.

Hall, S. (1992). The Question of Cultural Identity. In: Hall, S., Held, D., McGrew, T. (eds.). Modernity and its Future. Cambridge: Polity, pp. 273-326.

Hall, S. (1996). Introduction: Who Needs Identity? In: Hall, S., Du Gay, P. (eds.). Questions of Cultural Identity. London: Sage Publications, pp. 1-17.

Hazans, M. (2011). The Changing Face of Latvian Emigration, 2000-2010. In: Latvia. Human Development Report 2010/2011. National Identity, Mobility and Capability. Zepa, B., Kḷave, E. (eds.) Riga: Advanced Social and Political Research Institute of the University of Latvia, pp. 77-101.

Hazans, M. (2013). Emigration form Latvia: Recent Trends and Economic Impact. In: OECD Coping with Emigration in Baltic and East European countries, OECD Publishing, pp. 65-110.

Hazans, M. (2016). Atgriešanās Latvijā: remigrantu aptaujas rezultāti. Rīga: Latvijas Universitātes Diasporas un migrācijas centrs. http://www.diaspora.lu.lv/fileadmin/ user_upload/lu_portal/projekti/diaspora/petijumi/Atgriesanas_Latvija_petijuma_zinojums_FINAL03.pdf

Hedetoft, U. (2002). Discourses and Images of Belonging: Migrants Between "New Racism", Liberal Nationalism and Globalization. AMID Working Paper Series 5/2002.

Jenkins, R. (2008/1997). Rethinking Ethnicity. Second Edition. Sage Publications.

Jurkāne-Hobein, I. \& Kḷave, E. (2015). Krievvalodīgo latvijiešu Lielbritānijā un Zviedrijā transnacionālā piederība. Grām.: Latvijas emigrantu kopienas: cerību diaspora (red. Inta Mieriṇa). Rīga: Latvijas Universitāte, 180.-193. 
Kaprāns, M. (2015). Latviešu emigranti Lielbritānijā: transnacionālā identitāte un attālinātā nacionālisma konteksti. Grām.: Latvijas emigrantu kopienas: cerību diaspora (red. Inta Mieriṇa). Rīga: Latvijas Universitāte, 108.-127.

Kḷave, E. \& Šūpule, I. (2015). Reemigrācijas politika Latvijā: politika un prakse. Grām.: Latvijas emigrantu kopienas: cerību diaspora (red. Inta Mieriṇa). Rīga: Latvijas Universitāte, 194.-209.

Kḷave, E. \& Šūpule, I. (2017). Latvian and language competition in the diaspora (emigrant community). In: Language situation in Latvia: 2010-2015. A sociolinguistic study. (ed. L. Lauze). Available at: http://www.valoda.lv/en/297-2/ (last seen: 10.01.2018.)

Lulle, A., Kḷave, E., Reire, G., Birka, I. \& Ungure, E. (2015). Diasporas politiskā pārstāvniecība Latvijā un Eiropas Savienībā: parlamentārā dimensija, Latvijas Universitāte. Available at: http://www.diaspora.lu.lv/petijumi/ (last seen: 21.07.2015.)

Neuman, L. W. (2006). Social research methods: qualitative and quantitative approaches. $6^{\text {th }}$ edition. Boston: Pearson/Allyn and Bacon.

Potter, J. \& Wetherell, M. (1987). Discourse and Social Psychology: Beyond Attitudes and Behaviour. London: Sage Publications.

Saulītis, A. \& Mieriṇa, I. (2015). (Ne)pastāvošās Latvijas emigrantu kopienas ASV. Grām.: Latvijas emigrantu kopienas: cerību diaspora (red. Inta Mieriṇa). Rīga: Latvijas Universitāte, 161.-179.

Sussman, N. M. (2011). Return Migration and Identity: A Global Phenomenon, A Hong Kong. Hong Kong, Hong Kong University Press.

Šūpule, I., Krastiṇa, L. \& Peṇke, I. (2004). Ethnic Tolerance and the Integration of Latvian Society. Riga: Baltic Institute of Social Sciences.

Van Dijk, T. A., Ting-Toomey, S., Smitherman, G. \& Troutman, D. (1997). Discourse, Ethnicity, Culture and Racism. In: van Dijk, T. A. (ed.) Discourse as Social Interaction. Discourse Studies. A Multidisciplinary Introduction. Vol. 2. Sage Publications, pp. $144-180$.

Williams, A. M. \& Balaz, V. (2005). What Human Capital, Which Migrants? Returned Skilled Migration to Slovakia from the UK. International Migration Review, 39 (2), pp. 439-468.

Wodak, R., de Cillia, R., Reisigl, M. \& Liebhart, K. (1999). The Discursive Construction of National Identity. Edinburgh University Press.

Zepa, B., Šūpule, I., Kḷave, E., Krastiṇa, L., Krišāne, J. \& Tomsone, I. (2005). Ethnopolitical Tension in Latvia: Looking for the Conflict Solution. Riga: Baltic Institute of Social Sciences.

Zepa, B., Šupule I. \& Krastiṇa, L. (2011). Integration: Practice and Perspectives. A Sociological Study of Society Integration. LAP LAMBERT Academic Publishing GmbH \& Co. KG. 


\section{Appendix}

\section{Informants' characteristics}

\begin{tabular}{|c|c|c|c|c|c|c|c|}
\hline Nr. & Sex & Age & $\begin{array}{c}\text { Native } \\
\text { language }\end{array}$ & Occupation & $\begin{array}{c}\text { Year of } \\
\text { emigration }\end{array}$ & $\begin{array}{l}\text { Year of } \\
\text { return }\end{array}$ & Host country \\
\hline 1 & M & 47 & LV & IT expert & 2010 & 2013 & Norway \\
\hline 2 & M & 32 & LV & $\begin{array}{c}\text { Construction } \\
\text { work supervisor }\end{array}$ & 2009 & 2013 & Great Britain \\
\hline 3 & $\mathrm{~F}$ & 41 & LV & Preschool teacher & 2011 & 2013 & Great Britain \\
\hline 4 & M & 25 & LV & $\begin{array}{l}\text { Entrepreneur, } \\
\text { business } \\
\text { consultant }\end{array}$ & 2007 & 2013 & Great Britain \\
\hline 5 & $\mathrm{~F}$ & 30 & LV & Worker & 2010 & 2013 & Great Britain \\
\hline 6 & $\mathrm{~F}$ & 38 & LV & Self-employed & 2006 & 2011 & Ireland \\
\hline 7 & $\mathrm{~F}$ & 34 & LV & Shop manager & 2000 & 2010 & Great Britain \\
\hline 8 & M & 39 & $\mathrm{LV}$ & $\begin{array}{c}\text { Construction } \\
\text { work supervisor }\end{array}$ & 2009 & 2012 & $\begin{array}{l}\text { Norway, } \\
\text { Germany }\end{array}$ \\
\hline 9 & $\mathrm{~F}$ & 30 & LV & Economist & 2007 & 2011 & Ireland \\
\hline 10 & $\mathrm{~F}$ & 26 & RU & Finance analyst & 2007 & 2014 & USA \\
\hline 11 & M & 27 & RU & Tourist guide & 2009 & 2011 & Great Britain \\
\hline 12 & $\mathrm{~F}$ & 29 & LV & Translator & 2008 & 2013 & Norway \\
\hline 13 & M & 36 & LV & Mathematician & 2002 & 2007 & Germany \\
\hline 14 & M & 26 & LV & Political scientist & 2007 & 2013 & Great Britain \\
\hline 15 & M & 27 & LV & Hotel business & 2007 & 2013 & Great Britain \\
\hline 16 & $\mathrm{~F}$ & 29 & LV & $\begin{array}{c}\text { Pharmaceuticals, } \\
\text { lecturer }\end{array}$ & 2008 & 2012 & USA \\
\hline 17 & $\mathrm{~F}$ & 36 & LV & $\begin{array}{l}\text { Lawyer, } \\
\text { NGO's project } \\
\text { coordinator }\end{array}$ & 2010 & 2014 & Switzerland \\
\hline 18 & M & 33 & RU & IT expert & 2010 & 2014 & Great Britain \\
\hline
\end{tabular}

This study was supported by the interdisciplinary research project "The emigrant communities of Latvia: National identity, transnational relations, and diaspora politics" Nr. 2013/0055/1DP/1.1.1.2.0/13/APIA/VIAA/040, financed by the European Social Fund and carried out under the auspices of the Institute of Philosophy and Sociology, University of Latvia in cooperation with the Faculty of Economics and Management. 